\title{
Introduction to Part 4
}

Șūfism is the mystic and ascetic aspect of Islam. As such it is unrelated to the Shī'a-Sunnī split. One can be a Shī‘a or Sunnī and still be a Sūfi. Sūfism is about a way of believing and experiencing Islam rather than about a sectarian belief system. John Spencer Tirmingham (1971:2) called it the way which is aimed "at spiritual freedom whereby man's intrinsic intuitive spiritual senses could be allowed full scope." Despite the accusations of heresy by some Sunnī and Shī'a fundamentalists, Șūfi Muslims argue that their beliefs and practices are firmly rooted in the same sources of Islamic tradition that all Sunnīs and Shī'as hold as sacred, namely, the Qur'ān and sunna of the Prophet Muhammad. Muhammad, who Ṣufis claim was the first Șūfi master (murshid). While most Sūfis believe that Muhammad's cousin and the first Shī'a imām, 'Alī ibn Abì Ṭâlib, was the second in line after Muhammad and source of divine wisdom, some believe Abū Bakr, the first Sunnī khalīfa to have played that role.

Over time Șūfism was institutionalized into țarīqa, commonly known as orders. While many of these orders were regional and short lived, others became well established over vast regions and long periods of time. These include: Suhrawardiyya, Qādiriyya, Rifāiiyya, Kubrāwiyya, Chishtiyya, Shādhiliyya, Badawiyya (or Ahmadiyya), Mawlawiyah, and Naqshabandiyya (Tirmingham, 1971: 14). Distinctive features of institutionalized Șūfism outlined by Alexander Knysh (2017 6o-1) include revelatory knowledge of God, techniques and teachings are transmitted from masters to students, and that a follower (muridd) goes through stations (maqām) to gain ecstatic states $(h \bar{a} l)$. Devotional practices amongst Șüfis range from dhikr, repetition of the names of God and the scriptures, to quiet meditation, to lively dance and music.

This section starts with an overview of Șüfism, before moving on to look at the Khaniqahi Șúfi Order. The remaining three chapters describe regional variations in Șuffism and the ways in which this mystical tradition has influenced new religious movements and spiritual ideologies. This includes Subud, founded by an Indonesian student of Șufism, Muhammad Subuh, the life and ideas of René Guénon, a French Shadhili Șüf, and the teachings of the Greek-Armenian esotericist G.I. Gurdjieff. 


\section{References}

Knysh, A. 2017. Sufism: A New History of Islamic Mysticism. Princeton: Princeton University Press.

Kugle, S. 2007. Șūfis \& Saints' Bodies: Mysticism, Corporeality and Sacred Power in Islam. Chapel Hill: University of North Carolina Press.

Trimingham, J.R. 1971. The Süfi Orders in Islam. New York: Oxford University Press. 